\title{
The Role of Liquidity Management in Profitability: Case Study of Five Selected Commercial Banks of Iraq Stock Exchange over the Period (2006 - 2016)
}

\author{
1Shivan Hadi Ali, 2Shivan Abdulrahman Jameel \\ 1,2Banking \& Finance Department, Cihan University - Duhok, Duhok, Kurdistan Region - Iraq
}

\begin{abstract}
The purpose of this paper is to examine the role of liquidity management in the profitability of commercial banks listed on the Iraq Stock Exchange during the period 2006-2016. Data were collected from the annual financial statements of the banks. In order to analyze data, the current ratio (CR) was used as a proxy for liquidity as an independent variable while the return on assets (ROA) and the return on equity (ROE) were used as proxies for banks' profitability as dependent variables. The results of the study indicate that all of the variables under study are stationary at first differenced by utilizing Panel Unit Root Tests (Levin-Lin Chu and Hadri LM Methods). The outcomes of panel cointegration test showed that there is no long-term relationship among variables. In addition, the paper revealed that, in short term, the liquidity of banks plays an insignificant negative role in banks' profitability for both ROA and ROE by employing pooled regression model, Fixed Effect and Random Effect models. Therefore, this study recommended that banks' managers should take the advantage of investing their liquidity in various projects to obtain more profitability and then help governments to decrease their unemployment and recession in economy.
\end{abstract}

Keywords: Liquidity, banks profitability, Co-integration, Commercial Banks, Iraq Stock Exchange.

\section{Introduction}

\subsection{Background of the study}

The liquidity in the commercial bank represents the ability to fund its obligations by the contractor at the time of maturity, which includes lending and investment commitments, withdrawals, deposits, and accrued liabilities. Liquidity management takes one of two forms based on the definition of liquidity. One type of liquidity refers to the ability to trade an asset, such as a stock or bond, at its current price. The other definition of liquidity applies to large organizations, such as financial institutions. Banks are often evaluated on their

Academic Journal of Nawroz University

(AJNU) Volume 8, No 4 (2019).

Regular research paper : Published 1 Dec 2019

Corresponding author's e-mail : shivan.hadi@gmail.com Copyright (C2018 1Shivan Hadi Ali, 2Shivan Abdulrahman Jameel.This is an open access article distributed under the Creative Commons Attribution License. liquidity, or their ability to meet cash and collateral obligations without incurring substantial losses. In either case, liquidity management describes the effort of investors or managers to reduce liquidity risk exposure (Alshatti, 2015). Moreover, the concept of liquidity management is receiving serious attention all over the world particularly with the current financial situations and the state of the world economy (Ibe, 2013). The highest level of owner's net worth coupled with the attainment of other corporate objectives are achieved by some of the striking corporate goals include the need to maximize profit, maintain high level of liquidity in order to guarantee safety. Researchers cannot over emphasise the importance of liquidity management as it affects corporate profitability in today's business. The essential part in managing working capital is required maintenance of its liquidity in day-to-day operation to 
ensure its smooth running and meets its obligation (Eljelli, 2004).

On the other hand, Profitability is the important purpose of every business. Without profitability it is not easy to run your business as per continued business and the extension of business is not easy to create profit for short term business; it is necessary to create funds to fulfil its daily needs in operations and other wants, business generates more and more profits when this short term need of funds is generated by business process not by the external debt; hence, Profitability and liquidity is the most important part of business that gives complete information of business work Profitability and liquidity are used for long term in every business for strong work and promotion in the business; both liquidity and profitability are parallel to one another (Maqsood, Anwar, Raza, Ijaz, \& Shouqat, 2016). Therefore, liquidity plays a significant role in the successful functioning of a business firm. Consequently, a study of liquidity and its impact on profitability is of major importance to both the internal and the external analysts because of its close relationship with day-today operations of a business (Bhunia \& Malayendu, 2012). Dilemma in liquidity management is to achieve desired trade-off between liquidity and profitability (Nahum \& Amarjit, 2013). This study seeks among other things, to examine the problems of bank liquidity management in order to determine its effect on bank profitability.

\subsection{Research Problem}

Commercial bank has to work to maximize its profits and be able to meet the financial requirements of its depositors by holding a sufficient amount of liquidity simultaneously in order to achieve a balance between the profitability and liquidity. As stated by Alshatti (2015), banks should determine the optimal amount of cash that enable them in achieving balance between profitability and liquidity together because each level of liquidity has a different effect on the levels of profitability; therefore, the problem arises when commercial banks attempt to maximize their profits at the expense of neglecting the liquidity effect, which may cause a technical and financial hardship with the consequent withdrawal of deposits.

\subsection{Research Questions}

This research attempts to answer the following questions:

- What are the context of current ratio as independent variable and ROA and ROE as depended variables?

- To what extent does current ratio affect Iraqi commercial banks' ROA and ROE?

- What is the nature of the correlation among variables under study?

\subsection{Research Objectives:}

- To identify the concepts of liquidity management and bank profitability.

- To examine how liquidity management affect the Iraqi commercial banks' profitability.

- To determine the correlation between bank profitability and bank liquidity management.

\subsection{Research Hypothesis}

After reviewing the literature, the current study addresses the following hypotheses:

- This study assumes that there is a positive correlation among variables under study.

- The study assumes that there is a strong significant relationship among variables under study.

\subsection{Research Significance}

The study helps strengthening the banking sector by providing information on the liquidity management policies in regard to the profitability of Commercial Banks in Iraq. The results of the study can guide finance 
managers in banks to make sound investment decisions that will satisfy the stakeholders' interest with regard to liquidity and profitability needs of the investors. Identification of liquidity levels that maximize profits enables managers revise and adopt relevant strategies. Furthermore, the regulators will have evidence as to what levels of liquidity are present in profitable banks. This will help them formulate rules and regulations that help minimizing failure risk in the sector. Finally, the research adds to the body of knowledge in finance as well as further evidence on how banks are managed.

\section{Literature Review}

This research displays some of the previous studies about the role of liquidity management in banks' profitability. The literature review covers theoretical and conceptual framework on which the study leans, and a brief evaluation of what other authorities have documented on the subject of research.

\subsection{The Concept of Liquidity}

Liquidity is a financial notion that means the amount of capital that is available for investment. Today, most of this capital is in the form of credit, not cash. Bank Liquidity simply means the ability of the bank to retain sufficient funds to pay for its maturing obligations. It is the bank's ability to immediately meet cash, cheques, as well as other withdrawal obligations and legitimate new loan demand while abiding by existing reserve requirements (Ibe, 2013). Liquidity can also be defined as the degree of convertibility to cash or the ease with which any asset can be converted to cash (sold at a fair market price). Liquidity management therefore involves the strategic supply or withdrawal from the market or circulation the amount of liquidity consistent with a desired level of short-term reserve money without distorting the profit making ability and operations of the bank. It relies upon the daily assessment of the liquidity conditions in the banking system so as to determine its liquidity needs and thus the volume of liquidity to allot or withdraw from the market (Nwaezeaku, 2006).

Furthermore, bank liquidity can be defined as the ability to satisfy financial obligations as they come due. Consequently, Liquidity in a commercial bank reveals the bank's ability to finance all its contractual obligations when due, and those obligations can include lending, investment and withdrawal of deposits and maturity of liabilities, which happen in the normal course of the bank actions (Amengor, 2010). In addition, some of the theories are related to the concept of liquidity management as follow:

\subsubsection{Anticipated Income Theory}

According to Meghana (n.d.), this theory was developed by H.V. Prochanow in 1944 on the basis of the practice of extending term loans by the US commercial banks. As stated by Ibe (2013), the theory holds that a bank's liquidity can be operated through the accurate phasing and structuring of the loan commitments made by a bank to the customers. According to the theory, the liquidity can be planned if the programmed loan payments by a customer are based on the future of the borrower. It is emphasized that the theory points to the movement towards selfliquidating commitments by banks. Nzzotta (2004) reported that the theory emphasizes the earning potential and the credit worthiness of a borrower as the ultimate guarantee for ensuring sufficient liquidity. This theory encourages many commercial banks to adopt a ladder effects in investment portfolio.

\subsubsection{Shift-ability Theory}

The shift-ability theory of bank liquidity was propounded by H.G. Moulton who asserted that if the commercial banks retain a substantial amount of assets that can be shifted on to the other banks for cash without material loss in case of necessity, then there is 
no need to be dependent on maturities. According to this vision, an asset to be perfectly shift-able must be instantly transferable without capital loss when the need for liquidity arises. Additionally, this is particularly applicable to short term market investments, such as treasury bills and bills of exchange which can be instantaneously sold whenever it is necessary to raise funds by banks; while, in a general crisis when all banks are in need of liquidity, the shiftability theory requires that all banks should possess such assets which can be shifted on to the central bank which is the lender of the last resort. Furthermore, this theory has certain elements of truth. Banks now accept sound assets which can be shifted on to other banks. Finally, shares and debentures of large companies are acknowledged as liquid assets along with treasury bills and bills of exchange. This has encouraged term lending by banks. (Meghana, n.d.)

\subsubsection{Commercial Loan or Real Bills Doctrine Theory}

This theory states that a commercial bank ought to forward only short-term self-liquidating productive loans to business organizations. Loans intended to finance the production, and evolution of goods through the successive phases of production, storage, transportation, and distribution are considered as selfliquidating loans. Moreover, the theory states that whenever commercial banks make short term selfliquidating productive loans, the central bank should lend to the banks on the security of such short-term loans. This principle provides the appropriate degree of liquidity for each bank and appropriate money supply for the whole economy. Furthermore, the central bank was predicted to increase or erase bank reserves by rediscounting approved loans. When businesses start growing and the requirements of trade increase, then banks have the ability to capture additional reserves by rediscounting bills with the central banks. Inversely, when businesses go down and the requirements of trade decline, then the volume of rediscounting of bills would fall, the supply of bank reserves and the amount of bank credit and money would also contract. (Tutorialspoint.com)

\subsection{Liquidity Management}

Liquidity is a measure of the ability and ease with which assets can be converted to cash. Liquid assets are those that can be converted to cash quickly if needed to satisfy financial obligations; examples of liquid assets generally include cash, central bank reserves, and government debt. To remain feasible, a financial institution must have enough liquid assets to meet its near-term obligations, such as withdrawals by depositors. The main measures of liquidity are current ratio, capital ratio, cash ratio, quick ratio, investment ratio. (federalreserve.gov).

\subsection{The Concept of Banks Profitability}

Bank profitability is the ability of a bank to produce revenue in excess of cost, in relation to the bank's capital base. A sound and profitable banking sector is better able to endure negative shocks and contribute to the stability of the financial system (Brissimis Athanasoglou, \& Delis, 2005).

Generally speaking, profitability is a relationship between the profits generated by the enterprise and investments that contributed to the achievement of these profits, and profitability ratios measure the efficiency with which a company turns business activity into profits. Profit margins evaluate the ability to turn revenue into profits. Return on Assets (ROA) measures the ability to use assets to produce net income. Return on Equity (ROE) compares the net income to shareholder equity (Alshatti, 2015).

\subsection{Assessment the Bank's Profitability}

There are different financial ratios related to both the owners and depositors that can be applied in order to 
determine the extent of the bank ability to make profits from its invested money. The following two ratios are the most important earnings ratios used in assessing the bank profitability (Alshatti, 2015).

\subsubsection{Return on Assets (ROA)}

ROA ranks as one of the most widely used variables in shaping a firm's profitability. This ratio measure for the operating efficiency for the company based on the firm's generated profits from its total asset. It is calculated as net profit after tax divided by the total assets and can be expressed mathematically as follows: (Ayeni \& Adeyemi, 2017)

$$
\text { ROA }=\text { Net Profit After Tax / Total Assets }
$$

\subsubsection{Return on Equity (ROE)}

ROE is considered to be a vital important indicator that is the amount of net income returned as a percentage of shareholders' equity. The ratio measures the shareholders' rate of return on their investment in the company. It can be expressed mathematically as net profit after tax divided by the total shareholders' equity. (Kabajeh, AL Nu'aimat \& Dahmash, 2012)

ROE $=$ Net Profit After Tax $/$ Total Shareholders'Assets

\subsection{Empirical Evidence}

The impact of liquidity management on banks' profitability has been investigated by a number of researchers; here is some review of them. Previously, many research studies conducted to discover the nature of the relationship between liquidity and profitability. All the studies in this area were concluded with some similarities and differences to fill the research gaps. Therefore, the nature of the relationship between liquidity and profitability yet need to be resolved, as contrary results exist. The importance of this study is more valuable in the developing countries of the world where the overall business environment is more uncertain (Ismail, 2016).

The paper of Alshatti (2015) seeks at investigating the effect of liquidity management on profitability in Jordanian commercial banks over the period (20052012). The empirical results revealed a positive relationship between liquidity indicators (such as quick ratio and the investment ratio) and ROE; while, in the same study, the results were different that found a negative relationship between capital ratio and the liquid assets ratio as liquidity indicators and profitability. The investigator recommends that there is a need for an optimum utilization of the available liquidity in a various aspects of investment in order that the banks' profitability can be increased. The study also recommends that banks should adopt a general framework of liquidity management to assure sufficient liquidity for executing their operations more efficiently. Ismail (2016) investigated the impact of the liquidity management on the performance of the Pakistan nonfinancial companies constituting Karachi Stock Exchange (KSE) 100 Index over the period 2006-2011. The results of analyses have shown that liquidity variables [such as current ratio and the cash conversion cycle (CCC)] have significant positive impact on profitability (ROA). The paper recommended firms to relax their credit sales policies, and devise inventory collection rotation system in a wise manner to be more accessible to a large number of customers.

Bassey, Bassey and Ekwere (2016) attempted to investigate liquidity management and the performance of banks in Nigeria within the period 2000-2010. The findings of the correlation exhibited a positive relationship between cash reserve requirement and cash deposit and also a strong positive relationship between bank investment and cash ratio. Finally, the researchers recommended that banks should concentrate purely on deposits but rather other measures should be adopted 
to reduce liquidity in sector.

The study of Adebayo, David, and Samuel (2011) aimed at finding empirical evidence of the degree to which effective liquidity management affects profitability in commercial banks in Nigeria and how commercial banks can enhance their liquidity and profitability positions. The findings of Pearson correlation indicate that the significant positive relationship exists between liquidity and profitability. Furthermore, the study recommends that the Central Bank should be encouraged to maintain a flexible Minimum Monetary Policy [MPR] or discount rate in order to enable the commercial banks to take advantage of the alternative measures of meeting the unexpected withdrawal demands, and decrease the tendency of maintaining excess idle cash at the expense of profitability.

Malik and Ahmed (2013); Ajanthan (2013); Alavinasab and Davoudi (2013); Bolek (2013); Ajao and Small (2012); Azam and Haider (2011); Haq, Sohail, Zaman, and Alam (2011); Egbide, Uwuigbe, and Uwalomwa (2013); Uchenna, Mary, and Okelue (n.d.); Zainudin (2006) and Rahman (2011) in their research studied the influence of liquidity on return on assets (ROA). The results of studies demonstrated a significant positive relationship between current ratio (CR) and return on assets (ROA). The results are contradiction to the study conducted by Priya and Nimalathasan (2013) which revealed a negative relationship between liquidity and profitability.

Bhunia, Khan, and Mukhuti (2011) examined a mixed impact of liquidity on profitability during the investigation of the top four Steel companies in India. A result revealed that current ratio of both Tata and JSW Steels Ltd is positively related to profitability; whereas, for the other two steel companies (like Lloyds and Kalyani) it is negatively related to profitability. Kaur and Silky (2013) attempted to investigate all the companies listed on the National Stock Exchange of India to analyze the impact of working capital management in terms of liquidity management on profitability. The revealed result is in accordance with the trade-off theory that there is a negative relationship between current ratio and return on assets. Agha (2014) and Afeef (2011) demonstrated that there is no significant relationship exists between current ratio and profitability (ROA).

In the studies of all Ajanthan (2013); Egbide et al. (2013); Nimer, Warrad, and Omari (2013); Haq et al. (2011); Bhunia et al. (2011) for Lloyds Steel Ltd and Rahman (2011), it was revealed that there is a significant positive relationship between quick ratio and return on assets. The results of the studies are not in the line with studies conducted by Kaur and Silky (2013), Malik and Ahmed (2013) and Bhunia et al. (2011) for three Steel companies (namely: Tata, Kalyani and JSW) that found a negative relationship between quick ratio and return on assets.

The research of Ajanthan (2013) and Bhunia et al. (2011) for three Steel companies (namely: Tata, Kalyani and L1oyods) attempted to explore the relationship between liquidity and profitability. The results of their studies revealed that there is a positive relationship between cash ratio and profitability; while cash ratio of JSW Steel Ltd of the study of Bhunia et al. (2011) is negatively associated with profitability.

Alavinasab and Davoudi (2013); Anser and Malik (2013); Bolek (2013); Egbide et al. (2013); Makori and Jagongo (2013); Manyo (2013); Ajao and Small (2012); Ogundipe, Idowu, and Ogundipe (2012); Uremadu, Egbide, and Enyi (2012); Azam and Haider (2011) and Karaduman, Akbas, Ozsozgun, and Durer (2010) revealed that there is a negative relationship between CCC and return on assets (ROA). By contrast, only Padachi (2006) exhibited a positive relationship between CCC and ROA, which is in agreement with the 
view that resources are blocked at different stage of the supply chain, thus prolonging the operate cycle.

Afeef (2011) sought to investigate the impact of working capital management on the profitability of the firms. The research covered 40 small and medium enterprises listed on Karachi Stock Exchange during the period of 2003-2008. The study revealed that both independent variables (such as CCC and CR) are insignificantly positively related with ROA. Bagchi, Chakrabarti, and Roy (2012) examined the influence of working capital variables on the profitability of 10 Fast Moving Consumer Goods companies in India over the period of 2000-01 to 2009-10. The findings of the study by utilizing Pearson and regression analyses indicated a negative insignificant relationship between liquidity (such as CCC) and profitability (ROA). While, contrary to the traditional results, Spearman correlation coefficient indicated a positive significant relationship between the variables.

Molefe and Muzindutsi (2016) attempted to investigate the effect of capital and liquidity management on profitability in five leading South African banks for the period 2004 to 2014 . The empirical results revealed that there is no long-run relationship between banks' profitability and liquidity and capital management. Moreover, in the short term, capital ratio was found to have significant positive effect on banks' profitability when ROE was applied; while negative impact when ROA was applied. The result also showed that, in short term, quick ratio is negatively insignificantly related to both proxies of profitability (ROA and ROE). It concluded that capital adequacy is considered to be the most effective tool to ensure the safety and soundness of South African financial institutions.

Lartey, Antwi, and Boadi (2013) attempted to figure out the relationship between the liquidity and the profitability of banks listed on the Ghana Stock
Exchange. The paper revealed that over the period of 2005-2010, both the liquidity and the profitability of the listed banks were declining. Finally, it was found that there was a very weak positive relationship between the liquidity and the profitability of the listed banks in Ghana.

Finally, the study of Trabelsi (2015) aimed at investigating and evaluating the impact of the significant determinants of liquidity risk and the global financial crisis on the profitability of Islamic commercial banks in Bahrain over the period 2007-2013. The results showed that Capital adequacy, financial leverage, deposits and GDP have positive and significant impact on ROA; while bank size and the global financial crisis have negative significant impact on ROA. The researcher recommended that these banks should control and manage those variables properly in order to create a high level of liquidity in the banks which would achieve a good profitability, leading to the sustainability of the financial banking system.

\section{Research Methodology}

\subsection{Research Design:}

The nature of data consists of both time series and cross-sectional elements, which is known as a panel data. A starting point for analyzing panel data is the estimation of a panel regression. Moreover, it is important to determine which effects apply to the panel data while estimating a panel regression; on one hand, it could be a pooled regression, which would effectively assume that the intercepts are the same for each bank and for each year. on the other hand, it could be a fixed effect model (FEM) which assumes fixed effects for each bank and/or time-fixed effects and lastly, it could be a random effect model (REM), which assumes the effects are random along either the cross-sectional or the time dimensions (Brooks, 2014).

The following two models represent the research 
models:

$$
\begin{aligned}
& Y_{1 i t}=a_{0}+a_{1} x_{1 i t}+e_{1 i t} \\
& Y_{2 i t}=b_{0}+b_{1} x_{1 i t}+e_{2 i t}
\end{aligned}
$$

Where: $Y_{1 i t}$ represents the profitability for bank $\mathrm{i}$ at time $t$, measured by ROA;

$Y_{2 i t}$ represents the profitability for bank $\mathrm{i}$ at time $t$, measured by ROE;

$x_{1 i t}$ is the Current Ratio ( $\left.\frac{\text { Current Assets }}{\text { Current Liabilities }}\right)$ for bank $\mathrm{i}$ at time $\mathrm{t}$;

$a_{1}$ represents the coefficient of the ROA equation (equation 3);

$b_{1}$ represents the coefficient of the ROE equation (equation 4);

$a_{0}$ and $b_{0}$ represent the constant in ROA and ROE equations, respectively; and

$e_{1}$ and $e_{2}$ are the error terms in ROA and ROE equations, respectively.

The first equation (equation 3) estimates the current ratio on profitability when Return on Assets (ROA) is used as a proxy for profitability; while the second equation (equation 4) estimates the current ratio on profitability when Return on Equity (ROE) is applied as a proxy for profitability.

To check for stationarity of the variables, panel unit root test and co-integration are employed estimating the model. Firstly, the panel unit root test is conducted to determine whether the variables are stationary or non-stationary. Non-stationary variables can result in a spurious regression (Brook, 2014). Findings obtained from non-stationary data may exhibit a relationship between variables, where an actual relationship does not exist. The panel unit root test applied to determine the stationarity of the variables includes Levin-Lin-Chu and Hadri LM stationarity and this research compared results from these tests. In case the mentioned panel unit root tests reveal that variables are stationary or I (0), a normal panel regression can be estimated
(Gujarati \& Porter, 2008). By contrast, if variables are found to be non-stationary or I (1), a co-integration test is applied to see if the linear combination of these variables is stationary.

A panel co-integration model is employed to discover whether the variables tested are integrated, as well as to conclude whether there are long-run or short-run effects in the model. Most of the panel co-integration work so far has relied upon a generalization of the single equation methods of the Engle-Granger type following the pioneering work by Pedroni in 1994 and 2004 (Brooks, 2014). The Pedroni (Engle Granger) test is a less restrictive method of testing for co-integration and thus, is utilized in this study to conduct the panel co-integration tests. The presence of co-integration implies the long-run relationship between the variables and the error correction model (ECM) is then estimated. However, if there is no co-integration between variables, then panel regressions in Equation 3 and 4 are estimated at first differences. This is done to transform non-stationary data into stationary data in order to achieve consistent and reliable results (Iordanova, 2015). Finally, after checking for stationarity, the Hausman Test is conducted to find out the most appropriate model for the variables under the study.

\subsection{Data Collection and sampling}

This study applied the quantitative approach to investigate the role of liquidity management in banks' profitability in Iraq. The sample period consists of 55 annual data from five Iraqi commercial banks for the period 2006-2016. This means that a total of $55(5 \times 11)$ observations was utilized. The reason behind selecting the sample period was that because an eleven-year period provides sufficient room for analysis. A sample of five major commercial banks, namely Sumer commercial bank, Credit bank of Iraq, Investment bank 
of Iraq, North bank for finance and investment and Babylon bank were employed because they are the leading banks in Iraq and have significant influence on the country's financial sector. Variables used in the research include current ratio as a proxy for liquidity and return on assets (ROA) and return on equity (ROE) as measures of profitability. The data for all variables were obtained from Iraq Stock Exchange Database.

\subsection{Research Analysis}

Stata and EViews programs and descriptive statistical analysis, and regression models (that represent, the Pooled OLS, Fixed Effect Method and Random Effect Method) are applied to analyse the secondary data acquired for the five selected commercial banks in Iraq which were extracted from Iraq Stock Exchange Database.

\section{Results and Interpretation}

\subsection{Results of panel unit root tests}

Using the aforementioned three unit root tests, the following hypotheses can be developed:

Null Hypothesis $\left(H_{0}\right)$ : Panels contains unit roots (non-stationary)

Alternative Hypothesis $\left(H_{1}\right)$ : Panels do not contain unit roots (stationary)

The unit root findings are summarized in Table 1. The panel unit root test for ROA reveals that at level, the Levin-Lin-Chu method's p-value (0.0000) is less than 0.05; therefore, the null hypothesis is rejected and the alternative hypothesis is accepted which exhibits stationarity of panel data. Regarding the second test of panel unit root, Hadri LM method, the hypotheses that are developed would be the opposite, as follows:

Null Hypothesis $\left(H_{0}\right)$ : All panels are stationary

Alternative Hypothesis $\left(H_{1}\right)$ : Some panels contain unit roots

As can be seen from table 1, the Hadri LM method's pvalue at level, which is $(0.0000)$, is smaller than 5 percent significance level, meaning that the null hypothesis can be rejected that reveals the opposite result and does not confirm the stationarity of panel data used in the study, then the panel data for this variable by applying the second test reveals nonstationarity. Since one of the unit root tests reveal non stationarity of the data at level, the first difference could be derived utilizing the same mentioned above tests for checking stationarity. As a result, at first difference, the two methods show that panel data are stationary or $I$ (1) because the p-value of the first test used in the research (Levin-Lin-Chu), which is (0.0000), is smaller than $5 \%$ significance level, and the p-value of the second test (Hadri LM) that is nearly $(29 \%)$, is greater than 5\% significance level.

To conclude, ROA is found to be stationary or $I(1)$ by applying the two tests of checking stationarity at first difference.

Note that, the finding of the second dependent variable (ROE) reveals the same result at level employing the Levin-Lin Chu method; while applying the second method, it reveals different result that finds unit root in panel data. Therefore, the first difference is needed for the variable (ROE). Consequently, at first difference, ROE is also found to be stationary or I(1) by applying the two tests of checking stationarity.

In part $B$ of table 1 , unit root test for independent variable (current ratio), reveals that at level, the LevinLin-Chu method's p-value (1.0000) is more than (0.05) that shows the non-stationarity of the panel data while the p-value of Hadri LM test that is approximately $(46 \%)$ is greater than $(0.05)$ suggesting that panel data are stationary. Therefore, the first difference for this variable is also required to derive for checking stationarity. At first difference, results of Hadri LM method show that current ratio is stationary, meaning that it is I(1); while Levin-Lin-Chu method reveals unit 
root in panel data.

To summarize, current ratio is also found to be stationary or I(1) by applying panel unit root tests of checking stationarity at first difference.

Finally, according to the two methods (Levin-Lin-Chu and Hadri LM) utilized in the study for checking stationarity, the Panel Co-integration model can be run and developed by Eviews software since the tests can fulfill the model's condition. The precondition of panel co-integration model is the variable must be nonstationary at level (must have unit root) while becomes stationary after converting the data into first differenced.

Table 1: Panel Unit Root Test Results

\begin{tabular}{|c|c|c|c|c|}
\hline Part A & \multicolumn{2}{|l|}{ ROA } & \multicolumn{2}{|l|}{ ROE } \\
\hline Method & $\begin{array}{l}\text { Level } \\
p \text {-value }\end{array}$ & $\begin{array}{l}1^{\text {st }} \text { Difference } \\
p \text {-value }\end{array}$ & $\begin{array}{l}\text { Level } \\
p \text {-value }\end{array}$ & $\begin{array}{l}1^{\text {st }} \text { Difference } \\
p_{\text {-value }}\end{array}$ \\
\hline $\begin{array}{l}\text { Levin-Lin- } \\
\text { Chu }\end{array}$ & 0.0000 & 0.0000 & 0.0000 & 0.0000 \\
\hline \begin{tabular}{|l|}
$\begin{array}{l}\text { Hadri } \\
\text { test }\end{array}$ \\
\end{tabular} & 0.0000 & 0.2939 & 0.0000 & 0.2876 \\
\hline Part B & \multicolumn{4}{|c|}{ Current Ratio } \\
\hline Method & \multicolumn{2}{|l|}{$\begin{array}{l}\text { Level } \\
p \text {-value }\end{array}$} & \multicolumn{2}{|c|}{$\begin{array}{l}1^{\text {st }} \text { Difference } \\
p \text {-value }\end{array}$} \\
\hline $\begin{array}{l}\text { Levin-Lin- } \\
\text { Chu }\end{array}$ & \multicolumn{2}{|l|}{1.0000} & \multicolumn{2}{|l|}{0.1141} \\
\hline $\begin{array}{l}\text { Hadri LM } \\
\text { test }\end{array}$ & \multicolumn{2}{|l|}{0.4645} & \multicolumn{2}{|l|}{0.9648} \\
\hline
\end{tabular}

\subsection{Analysis of the long-run relationship}

Since variables under the research are I (1), the cointegration test was employed to test for the existence of the long-run relationship. The hypothesis test for cointegration is set as follows:

$H_{0}$ : There is no co-integration between liquidity ratio and banks' profitability.

$H_{1}$ : There is co-integration between liquidity ratio and banks' profitability.

Table 2: Pedroni co-integration results of ROA equation

\begin{tabular}{|l|l|l|l|}
\hline Method & $\begin{array}{l}\text { No } \\
\text { deterministic } \\
\text { tand P- }\end{array}$ & $\begin{array}{l}\text { With } \\
\text { intercept } \\
\text { and tmand }\end{array}$ & $\begin{array}{l}\text { Without } \\
\text { intercept and } \\
\text { tnand }\end{array}$ \\
\hline P-value & P-value \\
\hline $\begin{array}{l}\text { Panel v- } \\
\text { Statistic }\end{array}$ & 0.0024 & 0.4188 & 0.0006 \\
\hline $\begin{array}{l}\text { Panel rho- } \\
\text { Statistic }\end{array}$ & 0.3797 & 0.8458 & 0.4801 \\
\hline $\begin{array}{l}\text { Panel PP- } \\
\text { Statistic }\end{array}$ & 0.1135 & 0.5209 & 0.6076 \\
\hline $\begin{array}{l}\text { Panel ADF- } \\
\text { Statistic }\end{array}$ & 0.0324 & 0.3463 & 0.5844 \\
\hline
\end{tabular}

The findings of the Pedroni co-integration test in Table 2, for ROA equation, reveal that there is no cointegration among the variables. Since p-values of almost all of the panel v-statistic, panel rho-statistic, panel PP-statistic and panel ADF-statistic methods are greater than 5 percent, the null hypothesis for no cointegration cannot be rejected. Therefore, it is concluded that there is no long-run relationship between ROA as a proxy for profitability and Current Ratio as a proxy for liquidity.

Table 3: Pedroni co-integration results of ROE equation

\begin{tabular}{|l|l|l|l|}
\hline Method & $\begin{array}{l}\text { No } \\
\text { deterministic } \\
\text { trend }\end{array}$ & $\begin{array}{l}\text { With } \\
\text { intercept } \\
\text { and trend }\end{array}$ & $\begin{array}{l}\text { Without } \\
\text { intercept and } \\
\text { trend }\end{array}$ \\
\hline P-value & P-value & P-value \\
\hline $\begin{array}{l}\text { Panel v- } \\
\text { Statistic }\end{array}$ & 0.4151 & 0.8951 & 0.5473 \\
\hline $\begin{array}{l}\text { Panel rho- } \\
\text { Statistic }\end{array}$ & 0.1422 & 0.6007 & 0.2402 \\
\hline $\begin{array}{l}\text { Panel PP- } \\
\text { Statistic }\end{array}$ & 0.0048 & 0.0014 & 0.0539 \\
\hline $\begin{array}{l}\text { Panel ADF- } \\
\text { Statistic }\end{array}$ & 0.0060 & 0.0063 & 0.1915 \\
\hline
\end{tabular}

When the ROE was applied as a measure of profitability, the results in table 3 reveal the same outcome as there is no long-run relationship between $\mathrm{ROE}$ as a proxy for profitability and Current Ratio as a 
proxy for liquidity. The results are in accordance with the study of Molefe and Muzindutsi (2016) that exhibited no long-run relationship between banks' profitability and liquidity. This means that there may exist only short-run relationships between current ratio and profitability and it can be captured as a panel regression of first differenced series.

\subsection{Analysis of the short-run relationship}

The absence of a co-integrating relationship implies that panel regressions can be used to estimate the short-run effect of current ratio as a proxy for liquidity on ROA and ROE as proxies for profitability. Panel regressions contain three different models, namely pooled regression, fixed effects and random effects, known as the Error Components Model (ECM). Findings of these three mentioned models are provided in Table 5 and further tests were conducted to identify the best model that fit the data. The major problem with pooled regression model is that it does not distinguish between the various commercial banks used in the study. In other words, by combining five commercial banks by pooling, the method denies the heterogeneity or individuality that may exist among five commercial banks. Thus, the pooled OLS model could be ignored. This called for a second stage of using the Hausman test to determine whether the fixed effects model will be appropriate over the random effects model. The hypothesis developed by Hausman model is set as follows:

$$
\begin{aligned}
& H_{0} \text { : Random effect model is appropriate } \\
& H_{1} \text { : Fixed effect model is appropriate }
\end{aligned}
$$

Table 4: Hausman Test Results for ROA by using Random Effect model

\begin{tabular}{|l|l|l|l|}
\hline Test Summary & $\begin{array}{l}\text { Chi-sq. } \\
\text { Statistic }\end{array}$ & $\begin{array}{l}\text { Chi-sq. } \\
\text { d.f. }\end{array}$ & $\begin{array}{l}\text { Probability } \\
\text { value }\end{array}$ \\
\hline $\begin{array}{l}\text { Cross-section } \\
\text { random }\end{array}$ & 1.275460 & 1 & 0.2587 \\
\hline
\end{tabular}

The results for Hausman test in table 4 reveal that null hypothesis cannot be rejected in ROA equation, meaning that random effect model is appropriate over fixed effects model since the probability value, which is nearly $26 \%$, is more than 5 percent.

The findings of the study in table 5 show that the coefficient of current ratio at level is not statistically significant on ROA at the 0.05 significance level since the p-value that is roughly $(0.96)$ is more than $5 \%$. Moreover, current ratio at level affects the banks' profitability insignificantly negatively. Thus, current ratio has no significant effect on profitability when return on assets (ROA) is used as a proxy for profitability.

From the results of Hausman test for ROE in table 6, it can be seen that null hypothesis cannot be rejected meaning that the Hausman test supports the random effect model over fixed effects model because the probability value $(58 \%)$ is greater than 5 percent significant level.

Table 5: Panel Regression Analysis for ROA

\begin{tabular}{|c|c|c|c|c|c|c|}
\hline Variables & Pooled Regression & \multicolumn{2}{|c|}{$\begin{array}{c}\text { Fixed (LSDV) } \\
\text { Effect }\end{array}$} & \multicolumn{2}{c|}{ Random Effect } \\
\hline & Coefficient & P-value & Coefficient & P-value & Coefficient & P-value \\
\hline Cons. & 0.051198 & 0.0130 & 0.044226 & 0.0255 & 0.047121 & 0.0517 \\
\hline $\begin{array}{c}\text { Current } \\
\text { Ratio }\end{array}$ & -0.002533 & 0.7586 & 0.001091 & 0.8921 & -0.000414 & 0.9584 \\
\hline
\end{tabular}

Table 6: Hausman Test Results for ROE by using Random Effect model

\begin{tabular}{|l|l|l|l|}
\hline $\begin{array}{l}\text { Test } \\
\text { Summary }\end{array}$ & $\begin{array}{l}\text { Chi-sq. } \\
\text { Statistic }\end{array}$ & $\begin{array}{l}\text { Chi-sq. } \\
\text { d.f. }\end{array}$ & $\begin{array}{l}\text { Probability } \\
\text { value }\end{array}$ \\
\hline $\begin{array}{l}\text { Cross- } \\
\text { section } \\
\text { random }\end{array}$ & 0.301224 & 1 & 0.5831 \\
\hline
\end{tabular}

Table 7 presents the three panel regressions for ROE equation. As performed with the ROA equation, the pooled regression model was ignored and Hausman 
test was applied to determine the appropriate model which can be seen in table 6 .

The results of random effects model in table 7 demonstrate that the coefficient of current ratio is statistically insignificant at the 0.05 significance level (pvalue $>0.05$ ); current ratio has an insignificant negative effect on banks' profitability. Thus, when ROE is used as a proxy for profitability the current ratio is also insignificant determinant of banks' profitability.

Table 7: Panel Regression Analysis for ROE

\begin{tabular}{|l|l|l|l|l|l|l|}
\hline Variables & Pooled Regression & \multicolumn{2}{|l|}{ Fixed Effect } & \multicolumn{2}{l|}{ Random Effect } \\
\hline & Coefficients & $\begin{array}{l}\text { P- } \\
\text { value }\end{array}$ & Coefficients & $\begin{array}{l}\text { P- } \\
\text { value }\end{array}$ & Coefficients & $\begin{array}{l}\text { P- } \\
\text { value }\end{array}$ \\
\hline Cons. & 0.120829 & 0.0000 & 0.116639 & 0.0000 & 0.117545 & 0.0000 \\
\hline $\begin{array}{l}\text { Current } \\
\text { Ratio }\end{array}$ & -0.013772 & 0.0771 & -0.011594 & 0.1107 & -0.012065 & 0.0945 \\
\hline
\end{tabular}

\subsection{Discussion of results}

The role of liquidity management in profitability has been studied and examined for a long period of time by a variety of researchers to minimize risks associated with bank leverage and capital structure. The study analyzed the role of liquidity management in the profitability of five Iraqi commercial banks for the 11years period commencing from 2006 to 2016. The argument about the appropriate measure of profitability led to the use of ROA and ROE as the two common measures of profitability. Findings of the research reveal that these two measures of profitability have insignificant effect on the results, where the use of both ROA and ROE as proxies for profitability seems to produce insignificant results. This study found no evidence supporting a long-run relationship between bank profitability and the liquidity management since there is no co-integration between variables under study. The results of the study are in accordance with Molefe and Muzindutsi's (2016) findings that liquidity has no long-run effect on banks' performance in South
Africa. However, this result is contrary to study conducted by Adebayo et al. (2011) which found that liquidity and capital management have a long-run relationship effect on banks' profitability.

Short-run results and panel regression models reveal that the proxy used as measures of profitability have no significant effect on results as the current ratio was insignificant when ROA and ROE are used as proxies for profitability. Banks that are capital constrained are normally unwilling to or incapable of obtaining new equity in unfavorable times and are forced to deleverage by reducing lending, hence exacerbating the initial downturn (Behn Haselmann, \& Wachtel, 2015).

Furthermore, this study found that, in short term, an increase in current ratio led to a decline in profitability when both ROA and ROE are used to measure profitability. However, on both occasions, the coefficient for current ratio as a proxy for liquidity was insignificant, meaning that this study found no empirical evidence supporting the role of liquidity in promoting banks' performance in Iraq. Additionally, the result of the study, in terms of the direction of the relationship between dependent and independent variables, is in accordance with the research conducted by Priya and Nimalathasan (2013); Kaur and Silky (2013); Bhunia et al (2011) for Lloyds Steel Ltd and Kalyani Steels Ltd companies. However, this finding is contrary to many studies conducted by Malik and Ahmed (2013); Ajanthan (2013); Alavinasab and Davoudi (2013); Bolek (2013); Ajao and Small (2012); Azam and Haider (2011); Haq et al (2011); Ismail (2016); Egbide et al. (2013) and Rahman (2011); Bhunia et al (2011) for Tata Steel Ltd and JSW Steel Ltd companies; which exhibited that in commercial banks, profitability levels are significantly positively influenced by the banks' liquidity. This suggests that optimal use of liquidity is required to improve banks' profitability. 
Finally, In terms of the significance of the relationship, the study is in line with the study of Agha (2014) and Afeef (2011) that reveal the insignificant relationship between liquidity and profitability.

\section{Conclusion and recommendation}

\subsection{Conclusion}

Liquidity is one of the important indicators that show the process and results of qualified management in controlling analyzing the environment because it is the main factor that moves the local investment into international. Thus, managing this factor leads to a massive desired result.

Through the period chosen 2006-2016 many economic changes and challenges took place that affect the liquidity management; especially it is worth mentioning that countries faced the international crisis, and the recession still going on. Moreover, as a country has a policy depends on fiscal policy and public sector; liquidity should be managed in a way where it could be one of the backbones of economy in order to change an economy to a better situation as theories stated.

Furthermore, this study investigated the role of liquidity management in selected Iraqi banks' profitability and the findings showed the insignificant negative relationship between liquidity and profitability meaning that a rise in current ratio led to a reduction in profitability when both ROA and ROE are used to measure profitability. However, on both situations, the coefficient for current ratio as a proxy for liquidity was insignificant, meaning that this study found no empirical evidence supporting the role of liquidity in promoting banks' performance in Iraq.

\subsection{Recommendation}

The study recommended the following:

- It is a fundamentally important warning for management to take care to step up and take the chance to avoid negative impacts of having a large quantity of liquidity since that means the economy will face unemployment and recession and that will cost the government budget more pressures.

- It is also recommended that future studies should use more value creation measures and inclusion of other macroeconomic control variables to test the effect of liquidity management on profitability in the Iraqi commercial banks.

- Finally, the study recommends that banks should employ competent, professional and qualified personnel so that it can be guaranteed that right decisions are adopted especially with the optimal level of liquidity and maximizing profit.

\section{References}

1. Adebayo, O., David, A. O., and Samuel, O. O., (2011). Liquidity Management and Commercial Banks' Profitability in Nigeria. Research Journal of Finance and Accounting. Vol. 2, No. 7/8. PP: 24-38. Retrieved from http://www.iiste.org.

2. Afeef, M. (2011). Analyzing the Impact of Working Capital Management on the Profitability of SME's in Pakistan. International Journal of Business and Social Science, 2(22), 173-183.

3. Agha, H. (2014). Impact of Working Capital Management on Profitability. European Scientific Journal, 10(1), 374-381.

4. Alavinasab, S. M., \& Davoudi, E. (2013). Studying the relationship between working capital management and profitability of listed companies in Tehran stock exchange. Business Management Dynamics, 2(7), 1-8.

5. Alshatti, A. (2015). The Effect of the Liquidity Management on Profitability in the Jordanian Commercial Banks. International Journal of Business and Management. 10(1), 62-71.

6. Ajanthan, A. (2013). A Nexus between Liquidity and Profitability: A Study Of Trading Companies In Sri Lanka. European Journal of Business and Management, 5(7), 221-237.

7. Ajao, O. S., \& Small, O. S. (2012). Liquidity Management 
and Corporate Profitability: Case Study of Selected Manufacturing Companies Listed on the Nigerian Stock Exchange. Business Management Dynamics, 2(2), 10-25.

8. Amengor, E. C. (2010). Importance of Liquidity and Capital Adequacy to Commercial Banks. A Paper Presented at Induction Ceremony of ACCE, UCC Campus.

9. Anser, R., \& Malik, Q. A. (2013). Cash Conversion Cycle and Firms' Profitability - A Study of Listed Manufacturing Companies of Pakistan. IOSR Journal of Business and Management, 8(2), 83-87.

10. Ayeni, A. P., \& Adeyemi, A. O. (2017). Impact of Movement Pattern of Share Prices Among Quoted Banks In Nigeria. International Journal of Innovative Finance and Economics Research. 5(3), 1-11.

11. Azam, M., \& Haider, S. I. (2011). Impact of Working Capital Management on Firms' Performance: Evidence from Non- Financial Institutions of KSE-30 Index. Interdisciplinary Journal of Contemporary Research in Business, 3(5), 481-492.

12. Bagchi, B., Chakrabarti, J., \& Roy, P. B. (2012). Influence of Working Capital Management on Profitability: A Study on Indian FMCG Companies. International Journal of Business and Management, 7(22), 1-10.

13. Bassey, F. A., Tobi, E. G., Bassey, I. F., and Ekwere, R. E., (2016). Liquidity Management and the Performance of Banks in Nigeria over the period (2000 - 2010). International Journal of Academic Research in Accounting, Finance and management sciences. Vol. 6, No. 1, PP: 41-48.

14. Behn, M., Haselmann, R. and Wachtel, P. (2015). Procyclical capital regulation and lending. The Journal of Finance, 1(1):1-44.

15. Bhunia, A. and Malayendu, S., (2012). How far India has gone down the road towards financial integration with US since subprime crisis? An Econometric Analysis," MPRA Paper 38731, University Library of Munich, Germany.

16. Bhunia, A., Khan, I., \& Mukhuti, S. (2011). A Study of Managing Liquidity. Journal of Management Research, 3(2), 1-22.

17. Bolek, M. (2013). Profitability As A Liquidity And Risk
Function Basing On The New Connect Market In Poland. European Scientific Journal, 9(28), 1-15.

18. Brissimis, S., Athanasoglou, P., \& Delis, M. (2005). Bankspecific, Industry-specific and Macroeconomic determinants of bank profitability. Working Paper-Bank of Greece, $25 . \quad$ Retrieved from: http://www.bankofgreece.gr.

19. Brooks, C. (2014). Introductory Econometrics for Finance. 3rd ed. United Kingdom: Cambridge University Press. Available online at: http:/ / eprints.ucm.es/12285/1/1102.pdf Date of access: 21 May. 2017.

20. Egbide, B. C., Uwuigbe, O., \& Uwalomwa, U. (2013). Liquidity Management and Profitability of Manufacturing Companies in Nigeria. IOSR Journal of Business and Management, 9(1), 13-21.

21. Eljelli M. A. (2004). Liquidity-profitability tradeoff: An empirical investigation in emerging market. International Journal of Management, Vol. 14. Emerald Publishing Ltd.

22. Gujarati, D. N. and Porter, D. C. (2008). Basic Econometrics. 5th ed. New York: McGraw-Hill/Irwin.

23. Haq, I. U., Sohail, M., Zaman, K., \& Alam, Z. (2011). The Relationship between Working Capital Management and Profitability: A Case Study of Cement Industry in Pakistan. Mediterranean Journal of Social Sciences, 2(2), 365-372.

24. http://www.federalreserve.gov.

25. https://www.tutorialspoint.com/bank_management/b ank_management_liquidity_theory.htm

26. Ibe, S. O. (2013). The Impact of Liquidity Management on the Profitability of Banks in Nigeria. Journal of Finance and Banking Management, 1(1), 37-48. Retrieved from http://www.aripd.org/jfbm.

27. Iordanova, T. (2015). Introduction to Stationary and Non-Stationary Processes. Available online at: http://www.investopedia.com/articles/trading/07/sta tionary.asp Date of access: 21 May. 2017.

28. Ismail, R., (2016). Impact of Liquidity Management on Profitability of Pakistani Firms: A Case of KSE-100 Index. 304-314.

29. Kabajeh, M. A. M., AL Nu'aimat, S. M. A., \& Dahmash, 
F. N. (2012). The Relationship between the ROA, ROE and ROI Ratios with Jordanian Insurance Public Companies Market Share Prices. International Journal of Humanities and Social Science, 2(11), 115-120.

30. Karaduman, H. A., Akbas, H. E., Ozsozgun, A., \& Durer, S. (2010). Effects Of Working Capital Management On Profitability: The Case For Selected Companies In The Istanbul Stock Exchange (2005-2008). International Journal Of Economics And Finance Studies, 2(2), 47-54.

31. Kaur, S. S., \& Silky, J. (2013). A Study on Liquidity and Profitability of Selected Indian Cement Companies: A Regression Modeling Approach. International Journal of Economics, Commerce and Management, 1(1), 1-24.

32. Lartey, V. C., Antwi, S., and Boadi, E. K., (2013). The Relationship between Liquidity and Profitability of Listed Banks in Ghana. International Journal of Business and Social Science. Vol. 4 No. 3., PP: 48-56.

33. Makori, D. M., \& Jagongo, A. (2013). Working Capital Management and Firm Profitability: Empirical Evidence from Manufacturing and Construction Firms Listed on Nairobi Securities Exchange, Kenya. International Journal of Accounting and Taxation, 1(1), 1-14.

34. Malik, Q. A., and Ahmed, S. F. (2013). Idiosyncratic Effect of Liquidity Management Strategies on Corporate Performance Valuation-A Study of Chemical Industry. World Applied Sciences Journal, 28(1), 114-119.

35. Manyo, T. S. (2013). Does Cash Conversion Cycle Have Impact on Return on Assets of Nigerian Firms? Research Journal of Finance and Accounting, 4(14), 34-43.

36. Maqsood, T., Anwar, M., Raza, A., Ijaz, M. and Shouqat, U., (2016). Impact of Liquidity Management on Profitability in Banking Sector of Pakistan. International review of management and business review. 5(2), 643-652.

37. Meghana, S. (n.d.). Top Four Theories of Liquidity Managements. Retrieved from: http://www.microeconomicsnotes.com/banking/com mercial-banks/top-4-theories-of-liquiditymanagement/1234.

38. Molefe, B., and Muzindutsi, P. F., (2016). Effect Of Capital And Liquidity Management On Profitability Of
Major South African Banks. Proceedings of the 28th Annual Conference of the Southern African Institute of Management Scientists.

39. Nahum, N. and Amarjit, S. (2013). The impact of corporate governance on working capital management efficiency of American manufacturing firms, Emerald Publishing Ltd.

40. Nimer, M. A., Warrad, L., \& Omari, R. A. (2013). The Impact of Liquidity on Jordanian Banks Profitability Through Return on Assets. Interdisciplinary Journal of Contemporary Research in Business, 5(7), 70-76.

41. Nwaezeaku, N. C. (2006). Theories and Practice of Financial Management. Owerri. Ever Standard Publishing.

42. Nzzotta, S. M. (2004.) Money, Bankung and Finance: Theory and Practice. Owerri.

43. Ogundipe, S. E., Idowu, A., \& Ogundipe, L. O. (2012). Working Capital Management, Firms' Performance and Market Valuation in Nigeria. International Journal of Social, Human Science and Engineering, 6(1), 19-23.

44. Padachi, K. (2006). Trends in Working Capital Management and its Impact on Firms' Performance: An Analysis of Mauritian Small Manufacturing Firms. International Review of Business Research Papers, 2(2), 4558.

45. Priya, K., and Nimalathasan, B., (2013). Liquidity Management and Profitability: A Case Study of Listed Manufacturing Companies in Sri Lanka. International Journal of Technological Exploration and Learning, 2(4), 161165.

46. Rahman, M. M. (2011). Working Capital Management and Profitability: A Study on Textiles Industry. ASA University Review, 5(1), 115-132.

47. Trabelsi, M. K. (2015). The Impact of Liquidity Risk Determinants on Profitability: An Empirical Study on Islamic Banks in the Kingdom Of Bahrain. Othman YEOP Abdullah Graduate School of Business, University Utara Malaysia.

48. Uchenna, A. W., Mary, O. I., \& Okelue, U. D. (n.d.). Effects Of Working Capital Management On Profitability: Evidence From The Top five Beer Brewery 
Firms In The World. Asian Economic and Financial Review, 2(8), 966-982.

49. Uremadu, S. O., Egbide, B. C., \& Enyi, P. E. (2012). Working Capital Management, Liquidity and Corporate Profitability among quoted Firms in Nigeria Evidence from the Productive Sector. International Journal of Academic Research in Accounting, Finance and Management Sciences, 2(1), 80-97.

50. Zainudin, N., (2006). Liquidity-Profitability Trade-off: Is It Evident Among Malaysian SMEs? International Journal of Management Studies, 13(2), 107-118. 